\title{
Ernst Windisch
}

Geschichte der Sanskrit-Philologie

und Indischen Altertumskunde

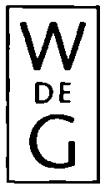





\title{
Geschichte der Sanskrit-Philologie und Indischen Altertumskunde
}

\author{
von \\ Ernst Windisch
}

I., II. Teil sowie nachgelassene Kapitel des III. Teils Um ein Namen- und Sachverzeichnis zum III. Teil erweiterter, ansonsten unveränderter Nachdruck der Ausgabe von 1917, 1920 und 1921

Walter de Gruyter · Berlin · New York 1992 
(@edruckt auf säurefreiem Papier, das die US-ANSI-Norm über Haltbarkeit erfüllt

Die Deutsche Bibliothek - CIP-Einheitsaufnahme

\section{Windisch, Ernst:}

Geschichte der Sanskrit-Philologie und Indischen Altertumskunde / von Ernst Windisch. -- Um ein Namen- und Sachverz. zum III. Teil erw., ansonsten unveränd. Nachdr. der Ausg. von 1917, 1920 und 1921. - Berlin ; New York : de Gruyter, 1992 ISBN 3-11-013013-0

(C) Copyright 1992 by Walter de Gruyter \& Co., Berlin 30.

Dieses Werk einschließlich aller seiner Teile ist urheberrechtlich geschützt. Jede Verwertung außerhalb der engen Grenzen des Urheberrechtsgesetzes ist ohne Zustimmung des Verlages unzulässig und strafbar. Das gilt insbesondere für Vervielfältigungen, Übersetzungen, Mikroverfilmungen und die Einspeicherung und Verarbeitung in elektronischen Systemen.

\section{Printed in Germany}

Druck: Werner Hildebrand, Berlin

Buchbinderische Verarbeitung: Lüderitz \& Bauer GmbH, Berlin 